\title{
The Subunit Structure of Prealbumin
}

\author{
By G. GONZALEZ* AND R. E. OFFORD \\ Laboratory of Molecular Biophysics, Department of Zoology, University of Oxford, \\ South Parks Road, Oxford OX1 3PS, U.K.
}

(Received 21 June 1971)

\begin{abstract}
1. Prealbumin, a thyroxine-binding protein, is known to bind also to retinolbinding protein and is suspected on X-ray-crystallographic evidence of having a quaternary structure. 2. Experiments described in this paper suggest that the molecule is a tetramer of mol.wt. about 56000 , which is disaggregated with some difficulty into subunits of mol.wt. about 14000. 3. The number and staining properties of the tryptic peptides indicate that the subunits are identical or closely similar. This conclusion is reinforced by comparing the sum of the amino acid compositions of the tryptic peptides with the amino acid composition of the whole protein. All minor peptides that were isolated could be shown to be derived from major peptides. 4. No evidence has been found, either from electrophoretic experiments or from amino acid sequence determination, for any dissimilarity between the subunits.
\end{abstract}

Plasma prealbumin has been recognized as one of the three proteins responsible for the transport of L-thyroxine in the blood stream (Robbins \& Rall, 1960; Ingbar, 1963; Oppenheimer, 1968). Recent reports have shown that prealbumin is also involved in the transport of vitamin $A$ in plasma. This is done in association with a specific retinolbinding protein (Kanai, Raz \& Goodman, 1968; Raz \& Goodman, 1969; Raz, Shiratori \& Goodman, 1970; Peterson, 1971a); the prealbumin-retinolbinding protein complex is able to combine with both thyroxine and retinol. This complex of hormone- and vitamin-binding protein is clearly of considerable interest. Prealbumin (Raz \& Goodman, 1969; Oppenheimer, Surks, Smith \& Squef, 1965; Purdy, Woeber, Holloway \& Ingbar, 1965 ; Schui uze, Heimburger \& Frank, 1962) and retinol-binding protein (Raz \& Goodman, 1969; Raz et al. 1970; Peterson \& Beggard, 1971; Peterson, 1971b) have now been purified and partly characterized.

By equilibrium-dialysis studies of the thyroxineprealbumin interaction, Raz \& Goodman (1969) found a molecular weight of about 50000. These authors found the same value by using the sedimentation-equilibrium technique and obtained results indicating that prealbumin consists of a single molecular species.

Peterson (1971a), by studying the interaction bstween prealbumin and the retinol-binding protein, found a molecular weight of about 17000 for

* On leave of absence (1968-72) from Departamento de Quimica, Universidad de Chile-Casilla 130-V, Valparaiso, Chile. prealbumin by gel filtration on a Sephadex G-200 column equilibrated with $5 \mathrm{M}$-guanidine hydrochloride.

In a crystallographic study Blake et al. (1971) have obtained evidence for a tetrameric structure for the prealbumin molecule. Examination of the molecular symmetry made it possible to define the quaternary structure of prealbumin as two pairs of non-identical subunits or four identical subunits. (This evidence is largely independent of ours but makes some use of the chemical work described in the present paper. Similarly we have benefited by knowing of the X-ray work in advance of publication.) Thus, in addition to its interactions with other molecules, prealbumin itself forms an associated system with a defined quaternary structure.

The experiments reported here were designed to obtain information about the molecular weight of prealbumin, to confirm the possible existence of subunits in the molecule and, if subunits do exist, to determine whether or not they are identical.

\section{MATERIALS AND METHODS}

Materials. Prealbumin was a gift of Dr K. Keide of Behringwerke A.G., Marburg/Lahn, West Germany. Trypsin was obtained from Worthington Biochemicals Corp., Freehold, N.J., U.S.A. (tosyl-pb^nylalanyl chloromethyl ketone Trypsin batch OFA). Phenyl isothiocyanate and pyridine (for Edman degradations only) were redistilled from AnalaR grade materials. Iodoacetic acid was recrystallized from petroleum ether (b.p. $60-80^{\circ} \mathrm{C}$ ). Iodo $\left[{ }^{14} \mathrm{C}\right]$ acetic acid was obtained from $\mathrm{The}$ Radiochemical 
Centre, Amersham, Bucks., U.K. at a specific radioactivity of $20 \mathrm{mCi} / \mathrm{mmol}$ labelled on the C-2 atom. It was diluted with the non-labelled material to a specific radioactivity of $1.66 \mathrm{mCi} / \mathrm{mmol}$ and stored as a frozen solution of the sodium salt $(6 \mathrm{mg} / \mathrm{ml})$ at $\mathrm{pH}$. Phenylthiohydantoin-glycine was obtained from Sigma (London) Chemical Co. Ltd., London S.W.6, U.K. Whatman papers were obtained from W. and R. Balston Ltd., Maidstone, Kent, U.K. Double-sided polyamide sheets were obtained from the Cheng-Chin Trading Co. Ltd., Taipei, Taiwan. All other reagents were AnalaR grade.

Gel-filtration. The protein was run in the absence of urea on a column ( $128 \mathrm{~cm} \times 2 \mathrm{~cm}$ diam.) of Sephadex G-100 equilibrated with $0.05 \mathrm{M}$-tris- $\mathrm{HCl}$ buffer, $\mathrm{pH} 7.5$, containing $0.1 \mathrm{M}-\mathrm{KCl}$. The flow rate was $1.3 \mathrm{ml} / \mathrm{min}$. Runs in the presence of urea were performed at $4^{\circ} \mathrm{C}$ on a column $(34 \mathrm{~cm} \times 0.75 \mathrm{~cm})$ of Sephadex G-100 equilibrated with $0.1 \mathrm{~m}$-tris-glycine buffer, pH9.5, in $6 \mathrm{M}$-urea and the flow rate was $0.05 \mathrm{ml} / \mathrm{min}$. Bovine serum albumin (Armour Pharmaceutical Co. Ltd., Eastbourne, Sussex, U.K.), ovalbumin, trypsin (Worthington) and ribonuclease (Sigma) were used as marker proteins in separate runs to estimate the approximate molecular weight (Andrews, 1964).

Polyacrylamide-gel electrophoresis. (a) In 6M-urea. Polyacrylamide-gel electrophoresis in $0.1 \mathrm{M}$-tris-glycine buffer, pH9.5, in $6 \mathrm{M}$-urea (final concentration) was performed as described by Davis (1964). The gel concentration used was $\mathbf{7 . 5} \%$ in acrylamide. Electrophoresis was performed at $30.7 \mathrm{~V} / \mathrm{cm}$ for $30 \mathrm{~min}$. The gels were stained after electrophoresis as described by Weber \& Osborn (1969).

(b) Hybridization. Hybridization experiments were performed by a method similar to that described by Markert (1963). Prealbumin samples dissolved in $\mathrm{NaCl}$ solutions were frozen at $-70^{\circ} \mathrm{C}$ for $30 \mathrm{~min}$ and then incubated for $30 \mathrm{~min}$ at $37^{\circ} \mathrm{C}$. This procedure was repeated three times. Different concentrations of protein $(0.1,1.0$ and $10.0 \mathrm{mg} / \mathrm{ml}$ ) and $\mathrm{NaCl}(0,1,2$ and $4 \mathrm{M})$ were employed. After this treatment the samples were submitted to polyacrylamide-gel electrophoresis at pH9.5 as desoribed above, but without urea.

(c) In sodium dodecyl sulphate. Polyacrylamide-gel electrophoresis in sodium dodecyl sulphate was performed as described by Weber \& Osborn (1969). Trypsin (Worthington), myoglobin, $\alpha$-lactalbumin (a gift of Dr R. Aschaffenburg) and pig insulin were used as marker proteins.

Reduction and carboxymethylation. Urea was added to protein $(5 \mathrm{mg} / \mathrm{ml})$ in $0.2 \mathrm{M}$-tris-EDTA buffer, $\mathrm{pH} 8.6$, until the solution was saturated. Dithiothreitol $(1 \mathrm{mg} /$ $50 \mathrm{mg}$ of protein) was added and $\mathrm{N}_{2}$ was bubbled into the solution to remove dissolved $\mathrm{O}_{2}$. The solution was allowed to stand for $1 \mathrm{~h}$ at room temperature under a $\mathrm{N}_{2}$ atmosphere to achieve full reduction. Solid iodoacetio acid was added as alkylating agent ( $1 \mathrm{mg} / 5 \mathrm{mg}$ of protein) and allowed to react for $20 \mathrm{~min}$ at room temperature. Excess of iodoacetic acid was eliminated by the addition of mercaptoethanol ( $1 \mathrm{mg} / \mathrm{mg}$ of iodoacetic acid). Extensive dialysis was performed before freeze-drying. The ${ }^{14} \mathrm{C}$ labelled iodoacetate solution was used in a similar manner. Amino acid analyses. Amino acid analyses were performed on samples hydrolysed in $6 \mathrm{M}$ - $\mathrm{HCl}$ under $\mathrm{N}_{2}$-flushed vacuum at $108^{\circ} \mathrm{C}$. The method used was that of Benson \&
Patterson (1965) by using a 120C Beckman Spinco automatic amino acid analyser.

$\mathrm{N}$-Terminal amino acid analysis of the protein. Qualitative $N$-terminal amino acid analyses were performed by the dansyl technique described by Gray \& Hartley $(1963 a, b)$. The reaction was performed in a ureasaturated solution; urea was largely removed by dialysis before acid hydrolysis of the sample. Identification was by two-dimensional chromatography on polyamide sheets (Woods \& Wang, 1969).

Quantitative $N$-terminal amino acid analyses were performed by using the Edman reaction modified as described by Konisberg (1967). Aq. 75\% (v/v) pyridine was used as the solvent for the reaction with phenyl isothiocyanate. The cyclization reaction was achieved by using anhydrous trifluoroacetic acid at room temperature for $80 \mathrm{~min}$. The cyclized product was dried, then dissolved in water. The extraction of the $N$-terminal amino acid derivative was performed three times with equal volumes of ethyl acetate. A measured sample of the cyclized material was taken for hydrolysis and amino acid analysis to determine the weight of protein present. The amount of $N$-terminal amino acid derivative was determined by recovery of the free amino acid after acid hydrolysis in $6 \mathrm{M}-\mathrm{HCl}$ for $24 \mathrm{~h}$ at $108^{\circ} \mathrm{C}$.

Tryptic digestion. It was found necessary to denature the carboxymethylated protein by boiling a solution $(3 \mathrm{mg} / \mathrm{ml}$ in water) for $3 \mathrm{~min}$, before cleavage by trypsin. After cooling the boiled suspension, $0.5 \mathrm{~g}$ of solid $\mathrm{NH}_{4} \mathrm{HCO}_{3}$ was added $/ 100 \mathrm{ml}$. Tosyl-phenylalanyl chloromethyl ketone-treated trypsin was added in the proportion $1: 100(\mathrm{w} / \mathrm{w})$ to the protein. The mixture was incubated at $37^{\circ} \mathrm{C}$ for $4 \mathrm{~h}$ and then freeze-dried. If denaturation was not performed, very little tryptic digestion occurred. This indicates the lack of any lasting effect of the denaturing conditions used in the alkylation.

Purification of peptides. (a) Gel filtration. The first step in the purification of the tryptic peptides was gel filtration on Sephadex G-50 in $0.5 \% \mathrm{NH}_{4} \mathrm{HCO}_{3}$. Up to $300 \mathrm{mg}$ of the peptide mixture, dissolved in $10 \mathrm{ml}$ of $0.5 \%$ $\mathrm{NH}_{4} \mathrm{HCO}_{3}$, was put on the column $(190 \mathrm{~cm} \times 4.2 \mathrm{~cm})$, which was eluted with the same buffer at a flow rate of about $3 \mathrm{ml} / \mathrm{min}$. The eluate was collected in $7 \mathrm{ml}$ fractions and peptides were located by the measurement of $E_{280}$ and by electrophoretic separation on paper at $\mathrm{pH} 6.5$ of portions of every third fraction (see Fig. 3). The effluent was pooled into eight fractions, each of which was freezedried and submitted first to high-voltage paper electrophoresis at $\mathrm{pH}$ 6.5.

(b) High-voltage paper electrophoresis. Peptide mixtures were separated by paper electrophoresis at 60$100 \mathrm{~V} / \mathrm{cm}$ in an apparatus similar to that described by Michl (1951), on Whatman 3MM and no. 1 papers at pH 1.9, 3.5, 6.5 or 8.9. Buffers and equipment were as described by, e.g., Ambler (1963). Cooling of the papers was by white spirit 100 (Esso Ltd.) with, in the case of the $\mathrm{pH} 6.5$ system, an admixture of pyridine $8 \%(\mathrm{v} / \mathrm{v})$.

(c) Paper chromatography. Peptides were separated by descending ohromatography with the solvent mixture butan-1-ol-acetic acid-water-pyridine (15:3:12:10, by vol.; Waley \& Watson, 1953) overnight at room temperature.

Paper chromatography was never used as the last step because of reports that peptides so prepared suffered 
destruction of amino acids on hydrolysis (Ambler, 1963). In this laboratory, similar problems have been experienced with some peptides in which electrophoresis at $\mathrm{pH} 6.5$ is used as the final purification step.

Peptide maps. About $0.1 \mu \mathrm{mol}$ of the tryptic digest was separated by electrophoresis as a $1 \mathrm{~cm}$ band on Whatman 3MM paper at pH 6.5. The strip of paper containing the separated peptides was then sewn for separation in a second dimension by descending ohromatography as described above. A number of duplioate maps were prepared for use with the different staining reactions.

Location of peptides on paper. Peptides were located on paper as described by Offord (1969). Ilford Industrial ' $G$ ' $\mathrm{X}$-ray film was used for radioautography.

Sequential Edman degradation of peptides. This technique was used with dansylation as described by Gray (1967).

\section{RESULTS AND DISCUSSION}

Gel filtration. The elution position of a protein on a Sephadex column may give an approximate measure of the molecular weight (Andrews, 1964). In the absence of urea, prealbumin was eluted at a position corresponding to a molecular weight of 57000 . In the presence of urea, prealbumin and carboxymethyl-prealbumin eluted at a position corresponding to mol.wt. either 30000 or 57000 depending on the mildness of the previous treatment of the protein. Remarkably, the lower-molecularweight peak predominated in those samples that had been mildly treated whereas the highermolecular-weight peak predominated after the more severe the treatment (such as brief boiling or boiling in saturated urea).

Polyacrylamide-gel electrophoresis. Electrophoresis of prealbumin in $6 \mathrm{M}$-urea showed no duplication of bands that might be ascribed to dissimilarity of charge between subunits. As with the gel filtration, the more severely the samples were treated before electrophoresis, the larger the apparent molecular weight. The single band (mobility $3.6 \mathrm{~cm} / \mathrm{h}$ toward the anode at $30.7 \mathrm{~V} / \mathrm{cm}$ ) shown by samples without pretreatment was replaced by a band of least mobility $10.8 \mathrm{~cm} / \mathrm{h}$ at $30.7 \mathrm{~V} / \mathrm{cm}$ if the samples were boiled before electrophoresis.

Samples of eluate from the protein-peak tubes of the gel-filtration experiments were run direct on polyacrylamide gels (the buffers were the same). Material from the $30000 \mathrm{~mol}$.wt. position gave only the fast band whereas material from the $57000 \mathrm{~mol}$.wt. position gave only the slow band.

We are unable to explain the apparent increase of molecular weight after treatment that should have decreased the molecular weight. However, the purpose of the experiments was to look for evidence of charge differences between subunits and there was certainly none.

Hybridization. As the previous experiments showed no charge differences between subunits, it was not surprising that there was no evidence for formation of hybrid molecules under any of the conditions tried. In each case freezing and thawing did not alter the electrophoretic behaviour of the protein.

Polyacrylamide-gel electrophoresis in sodium dodecyl sulphate. Fig. 1 shows the results of a typical run. Under the disaggregating conditions of the experiment the molecular weight of prealbumin was decreased to about 14000. This is about onequarter of the value determined by gel filtration and by X-ray crystallography (Blake et al. 1971) and is consistent with the existence of four subunits for the prealbumin molecule. The peak (mol.wt. 30000) seen in $6 \mathrm{M}$-urea could thus be a dimer.

Amino acid composition. The results of the amino acid analysis of prealbumin are given in Table 1. Molar ratios are given on the basis of 16 histidine residues, a value which brings the total molecular weight $(56000)$ nearest to that beginning to become apparent for the whole molecule. Values are also given for a total chain length of one-quarter of this value, which is suggested for the subunit size by the gel-electrophoresis experiments.

It appears, therefore, that urea is inadequate for the complete disaggregation of the molecule. It has already been mentioned that urea treatment does not cause any lasting disruption of the tertiary structure.

N-Terminal amino acid determination. The $N$. terminal amino acid of prealbumin was identified

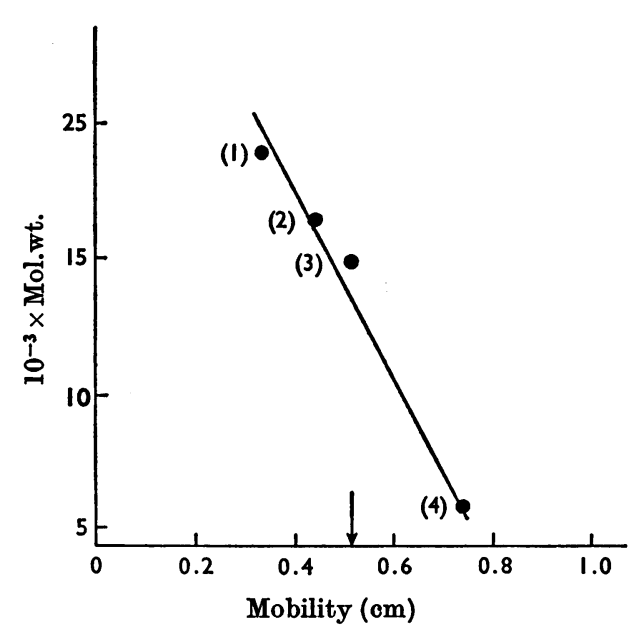

Fig. 1. Determination of the molecular weight of the subunits of prealbumin by sodium dodecyl sulphate electrophoresis. The arrow indicates the mobility of prealbumin. The interpolated value for the molecular weight of the prealbumin subunits is 14000 . (1) Trypsin; (2) myoglobin; (3) $\alpha$-lactalbumin; (4) insulin. Experimental details are given in the text. 
Table 1. Amino acid composition of prealbumin

For experimental details see the text. The corrected distribution is the average value for all the amino acids except for threonine and serine (for which the observed values were extrapolated back to zero time), and for valine and isoleucine (for which the observed values were plotted against $1 / t$ and extrapolated to $1 / t=0$ ).

Amino acid Hydrolysis time ...

Lys

His

Arg

Asp

Thr

Ser

Glu

Pro

Gly

Ala

Cys

Val

Met

Ile

Leu

Tyr

Phe

Trp
Content (nmol)

$\begin{array}{rrr}24 \text { h } & 48 \text { h } & 96 \text { h } \\ 204 & 194 & 201 \\ 94 & 90 & 94 \\ 94 & 90 & 90 \\ 178 & 194 & 192 \\ 258 & 252 & 249 \\ 220 & 222 & 192 \\ 310 & 309 & 313 \\ 190 & 189 & 203 \\ 232 & 230 & 236 \\ 280 & 289 & 279 \\ & & \\ 241 & 266 & 284 \\ & & \\ 105 & 109 & 113 \\ 168 & 168 & 147 \\ 107 & 108 & 106 \\ 111 & 113 & 108\end{array}$

Number of residues

Corrected
distribution (nmol)

200

92

91

188

260

225

309

193

233

282

291

115

161

107

117 relative to histidine

\begin{tabular}{cc}
\hline His $=16$ & His $=4$ \\
34.8 & 8.7 \\
16.0 & 4.0 \\
15.8 & 3.9 \\
32.7 & 8.2 \\
45.2 & 11.3 \\
39.1 & 9.8 \\
53.8 & 13.4 \\
33.6 & 8.4 \\
40.5 & 10.1 \\
49.1 & 12.3 \\
$4.0^{*}$ & $1.0^{*}$ \\
50.6 & 12.6 \\
$4.0^{*}$ & $1.0^{*}$ \\
20.0 & 5.0 \\
28.0 & 7.0 \\
18.6 & 4.6 \\
19.3 & 4.8 \\
$16.6 \dagger$ & $4.1 \dagger$
\end{tabular}

* Values obtained by analysis of three more samples (24h hydrolysed), after performate oxidation at $0^{\circ} \mathrm{C}$ (Hirs, 1956).

$\dagger$ Trp/Tyr ratio $=1: 1.1$. Method of Goodwin \& Morton (1946).

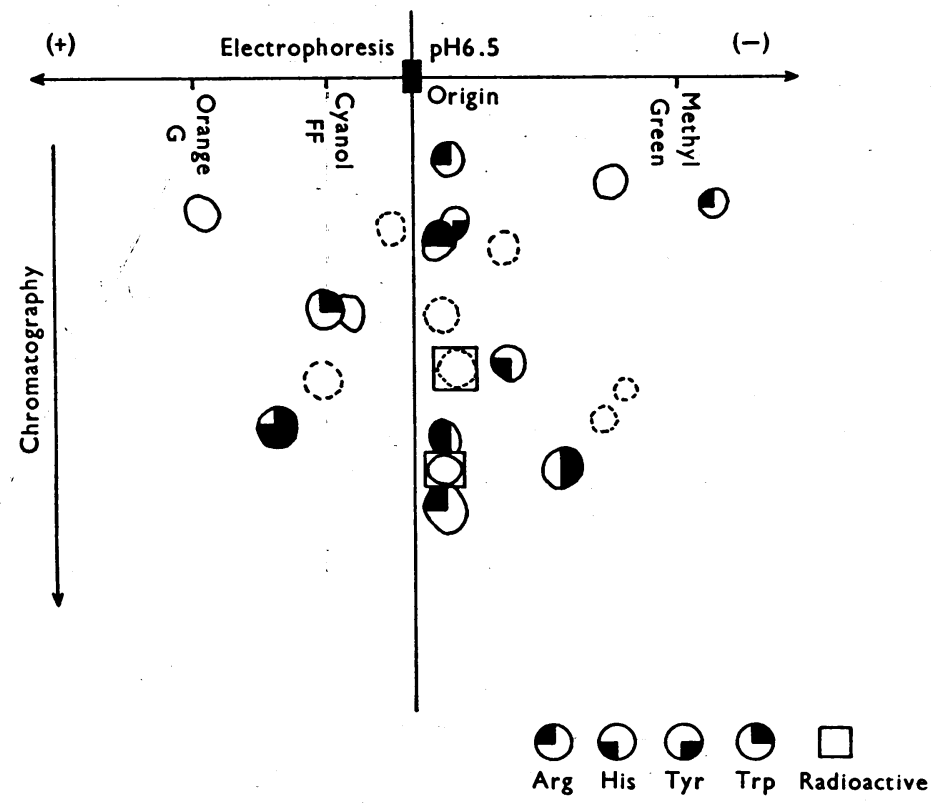

Fig. 2. Peptide 'map' after tryptic digestion of prealbumin. Broken lines indicate minor peptides. The symbols representing the different amino acids stained for, and the symbol showing the radioactive peptide, are indicated on the figure. Experimental details are given in the text. 
Table 2. Peptide counting

For experimental details see the text.

\begin{tabular}{lccc} 
& \multicolumn{2}{c}{ Predicted value } & \\
\cline { 2 - 4 } $\begin{array}{c}\text { No subunits } \\
(\text { or } \alpha \beta \gamma \delta)\end{array}$ & $\begin{array}{c}\text { Four identical } \\
\text { subunits }\end{array}$ & $\begin{array}{c}\text { Observed value } \\
\text { 14 major } 7 \text { minor } \ddagger\end{array}$ \\
$\begin{array}{c}\text { Total no. of } \\
\text { tryptic peptides }\end{array}$ & $52^{*}$ & $14^{*}$ & 3 \\
Histidine staining & 16 & 4 & 3 \\
Arginine staining & 16 & 4 & 3 \\
Tyrosine staining & 18 & 5 & 4 \\
Tryptophan staining & 16 & 4 & 1 major 1 minor $\ddagger$ \\
Radioactive† & 4 & 1 &
\end{tabular}

* Number of unique lysine residues + number of unique arginine residues +1 .

$\dagger$ With iodo $\left[{ }^{14} \mathrm{C}\right]$ acetate.

$\ddagger$ See Table 5 .

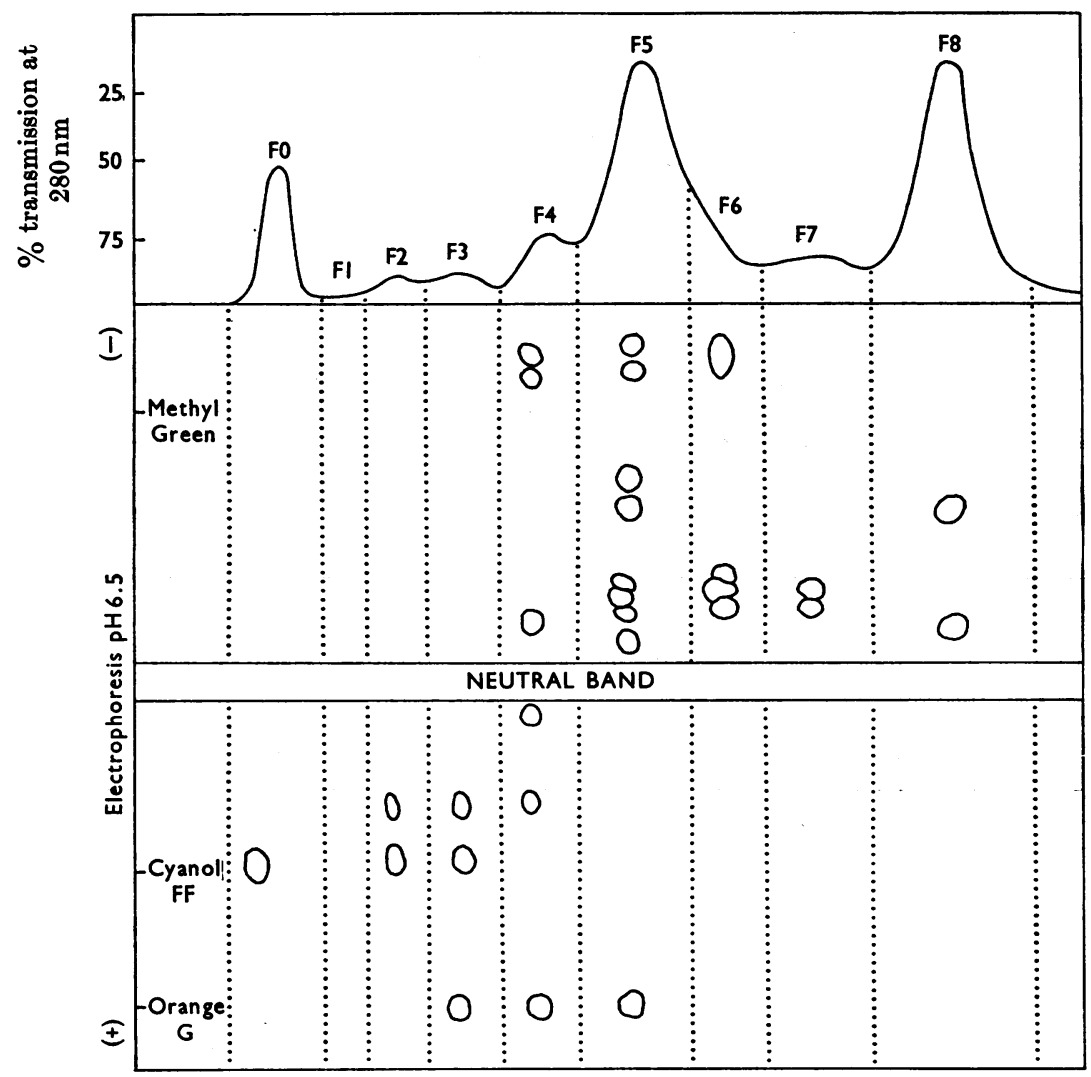

Fig. 3. Gel filtration of a tryptic digest of carboxymethylated prealbumin. Samples of effluent fractions were submitted to electrophoresis at pH 6.5 and the pattern of the peptides is shown below the effluent curve. The eluates were combined to give eight separate fractions as indicated. Fraction F0 corresponds to undigested prealbumin, some of which always remained even after the denaturation process described in the Materials and Methods section. For experimental details see the text. 
by using the dansyl method; the reaction was performed in the presence of urea in an attempt to maximize the access of the reagent to the terminal part of the polypeptide chain. The result showed glycine to be the sole amino acid in prealbumin with a free $\alpha$-amino group.

The Edman reaction was used for the quantitative determination of glycine at the $N$-terminus of the protein. The method chosen was the release of glycine as its phenylthiohydantoin derivative, from which the free amino acid was regenerated by acid hydrolysis. The recovery of glycine was estimated by submitting a spectrophotometrically determined sample of phenylthiohydantoin-glycine (previously shown to be uncontaminated by the free amino acid) to the same conditions of hydrolysis as the experimental sample. The yield obtained from this sample was $19 \%$. The uncorrected recovery of glycine from the experimental sample was $1 \mathrm{~mol} /$ $76900 \mathrm{~g}$ of protein; that is, after correction, one residue of $N$-terminal glycine $/ 15380 \mathrm{~g}$ of protein. This implied value for the subunit size corresponds approximately to one-quarter of the molecular weight of the undissociated protein.

Peptide 'maps'. The pitfalls of using peptide 'maps' to determine molecular weights are well known (Harris \& Hindley, 1965; Fraenkel-Conrat, 1965). However, with suitable safeguards, peptide 'maps' (Fig. 2) could be used in the present case to give at least a preliminary estimate of the size and number of the subunits.

Table 2 shows the number of peptides to be expected $(a)$ if the total of 56000 is made up of a single chain, or four completely dissimilar subunits $(\alpha \beta \gamma \delta) ;(b)$ if there were four identical subunits $\left(\alpha_{4}\right)$. Other cases, such two pairs of identical sub. units $\left(\alpha_{2} \beta_{2}\right)$ will give values intermediate between these extremes depending on the extent to which sequences are duplicated between subunits.

There is very little insoluble material in the digest and thus a common source of error in counting the peptides (the accumulation of a number of different peptides in a single spot at the origin) may be assumed to be absent. Therefore the count is certainly sufficient to eliminate the possibility that prealbumin is a single chain of mol.wt. 56000, or four dissimilar subunits, or even the total dissimilarity of $\alpha$ and $\beta$ in the event of the structure being $\alpha_{2} \beta_{2}$.

It is not possible to conclude more than that the prealbumin structure approximates to $\alpha_{4}$ or a close variant (a result also suggested by the sodium dodecyl sulphate electrophoresis and by the $N$. terminal work) without isolating the individual peptides and determining whether or not they are all unique sequences. This is a necessary preliminary to the determination of the complete amino acid sequence of the protein, to which we are committed as a necessary adjunct to the interpretation of high-resolution X-ray results being obtained in this laboratory.

Purification of the tryptic fragments. The methods used for purification are described in the Materials and Methods section. Fig. 3 shows the elution pattern of the initial gel filtration. Table 3 indicates the sequence of steps used to purify the major peptides.

Nature of the tryptic fragments. Table 4 shows the amino acid composition of the major unique fragments. A number of other fragments isolated had compositions related to those of the major fragments (Table 5).

Table 3. Purification scheme for the tryptic peptides

For experimental details see the text. Solvent BAWP is butanol-acetic acid-water-pyridine (15:3:12:10, by vol.). Purification steps (numbers indicate the order followed)

\begin{tabular}{|c|c|c|c|c|c|}
\hline Peptide & Sephadex G-50 & $\begin{array}{c}\text { Electrophoresis } \\
\text { at pH 6.5 }\end{array}$ & $\begin{array}{c}\text { Paper chromato- } \\
\text { graphy in solvent BAWP }\end{array}$ & $\begin{array}{c}\text { Electrophoresis } \\
\text { at pH 3.5 }\end{array}$ & $\begin{array}{c}\text { Electrophoresis } \\
\text { at pH } 8.9\end{array}$ \\
\hline F4N3 & 1 & 2 & 3 & & 4 \\
\hline F4N4 & 1 & 2 & 3 & 4 & \\
\hline F5N1 & 1 & 2 & 3 & 4 & \\
\hline F5N5-3 & 1 & 2 & 3 & 4 & $\mathbf{5}$ \\
\hline F6N5 & $\mathbf{1}$ & 2 & 3 & 4 & \\
\hline F5B5 & $\mathbf{l}$ & 2 & 3 & 4 & \\
\hline F5B7-2 & 1 & 2 & 3 & & 4 \\
\hline F8B2 & 1 & 2 & 3 & 4 & \\
\hline F2A1 & 1 & 2 & & & $\mathbf{3}$ \\
\hline F2A2 & 1 & 2 & 3 & 4 & \\
\hline F5A5-2 & 1 & 2 & 3 & 4 & \\
\hline F5A1 & 1 & 2 & & & \\
\hline F6B1 & 1 & 2 & & & \\
\hline
\end{tabular}




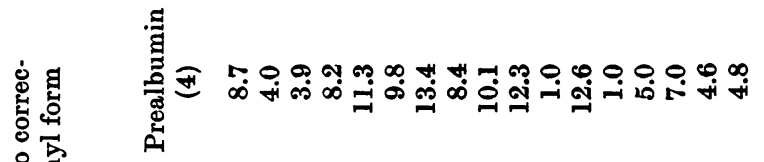

乙

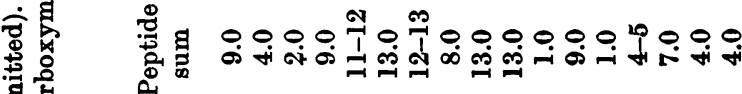

:

离

$\stackrel{*}{*}$

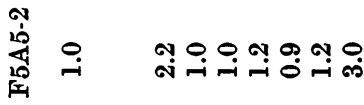

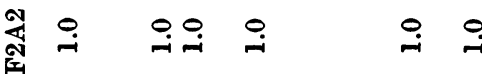

-

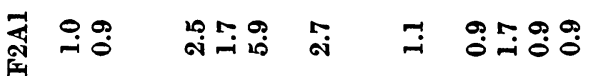

:

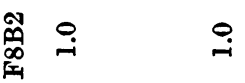

$\stackrel{\circ}{-}$

离

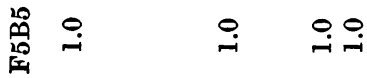

䕇

$\stackrel{ }{-} \stackrel{\circ}{\circ} \stackrel{\circ}{-}$

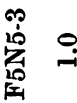

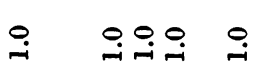

究

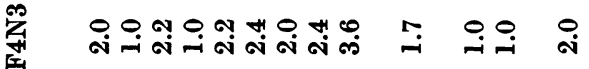

萦

象

要

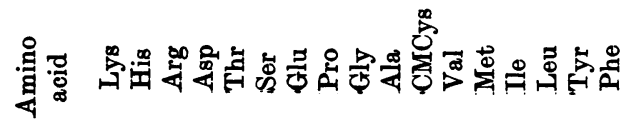


Table 5. Minor peptides obtained from the tryptic digest

Peptide F5N4 was radioactive before hydrolysis. Experimental details are given in the text. CMCys, $S$-carboxymethylcysteine.

Minor peptide
F5A63
F5B4
F5A43
F5A32
F5N4

\author{
Composition \\ $\mathrm{Lys}_{2.0} \mathrm{Asp}_{2.4} \mathrm{Thr}_{1.0} \mathrm{Ser}_{1.0} \mathrm{Glu}_{1.2}$ \\ $\mathrm{Pro}_{1.7} \mathrm{Gly}_{1.3} \mathrm{Ala}_{3.7} \mathrm{Phe}_{1.1}$ \\ $\mathrm{Lys}_{1.0}$ Val $_{1.0}$ \\ $\mathrm{CMCys}_{1.0}$ Pro $_{1.0}$ Leu $_{1.0}$ Met $_{1.0}$ \\ $\mathrm{Asp}_{1.1} \mathrm{Glu}_{0.9} \mathrm{Ala}_{2.0} \mathrm{Phe}_{1.7}$ \\ $\mathrm{Lys}_{1.0}$ Pro $_{1.0}$ Val $_{1.0}$ Met $_{1.0}$ Leu $_{1.0}$
}

$\begin{gathered}\text { Related major } \\ \text { peptide }\end{gathered}$
F5A52
F5N53
F5N53
F4N3
F5N5-3

\author{
Reason for occurrence \\ Shown to have extra Lys at \\ $N$-terminus. \\ Chymotryptic split after Met. \\ Chymotryptic split after Met. \\ Chymotryptic split? \\ Atmospheric oxidation of CMCys \\ residue (e.g. Harris, 1967) causing \\ change of mobility.
}

Table 6. Preliminary sequence data on the tryptic peptides

\begin{tabular}{ll}
\multicolumn{2}{c}{ For experimental details see the text. } \\
Peptide & $\begin{array}{c}\text { Sequence (complete or partial) determined } \\
\text { by dansyl-Edman degradation }\end{array}$ \\
F4N3 & Ala-Leu-Gly-Ile-Ser \\
F4N4 & Ala-Leu-Leu \\
F5N1 & Gly-Pro-Thr-Gly-Thr-Gly-Glu-Ser-Lys \\
F5N5-3 & CMCys-Pro-Leu-Met-Val-Lys \\
F6N5 & Val-Leu-Asp-Ala-Val-Arg \\
F5B5 & Ala-Ser-Gly-Lys \\
F5B7-2 & Gly-Ser \\
F8B2 & Ser-Tyr-Trp-Lys \\
F2A1 & Thr-Ser-Glx-Ser-Gly-Glx-Leu-Glx-Gly \\
F2A2 & Val-Glu-Ile-Asp-Thr-Lys \\
F5A5-2 & Ala-Ala-Asx-Asx-Thr
\end{tabular}

Of the fragments present in sufficient quantity to be isolated, none had amino acid compositions irreconcilable with those of the major fragments. Before a complete overlapping sequence is obtained it is not possible to be sure that every part of the molecule had been recovered in the form of a tryptic peptide. However, the summation in Table 4 makes it seem unlikely that any great portion can be missing. Taken with all the other evidence, the summation indicates that the molecule must be made up of four subunits and that, if the subunits differ in sequence, they can do so only slightly. This conclusion is strengthened by the sequence information so far obtained (Table 6). If there were slight differences between subunits one might expect to find peptides with almost identical sequences, or alternatively a difference could occur that might not be sufficient to permit separation of two forms of a peptide. In the latter case there should be ambiguities in the sequences at the position of the difference. The results in Table 6 do not indicate that such ambiguities occur although they cannot be absolutely ruled out until the sequence work is complete. [A parallel study of the sequence of prealbumin is being performed by using an automatic Edman degradation machine (R. E. Canfield \& F. J. Morgan, personal communication). We have seen the preliminary results of the above work and, for regions where both groups have sequence results, find no great discrepancy between the results obtained by the two approaches.]

Conclusion. The results presented above indicate that prealbumin is composed of four polypeptide chains, each having a molecular weight of about 14000. There is no evidence inconsistent with the view that the four chains have an identical amino acid sequence but the possibility that there are small dissimilarities cannot be eliminated until the complete sequence is determined.

We thank Dr K. Keide for gifts of prealbumin, Dr C. C. F. Blake for showing us preliminary $X$-ray data and Dr R. Canfield and Dr F. Morgan for showing us sequence results. We thank the Medical Research Council for financial assistance and also Merck, Sharp and Dohme Ltd. (R.E.O.) and St John's College, Oxford (G.G.). 


\section{REFERENCES}

Ambler, R. P. (1963). Biochem. J. 89, 349.

Andrews, P. (1964). Biochem. J. 91, 222.

Benson, J. V. \& Patterson, J. A. (1965). Analyt. Chem. 37, 1108.

Blake, C. C. F., Swan, I. D. A., Berthou, J., Laurent, A., Rerat, J. \& Rerat, C. (1971). J. molec. Biol. (in the Press).

Davis, B. J. (1964). Ann. N.Y. Acad. Sci. 121, 404.

Fraenkel-Conrat, H. (1965). In The Proteins, vol. 3. Ed. by Neurath, H. New York: Academic Press Inc.

Goodwin, T. W. \& Morton, R. A. (1946). Biochem. J. 40, 628.

Gray, W. R. (1967). In Methods in Enzymology, vol. 11, p. 469. Ed. by Hirs, C. H. W. London: Academic Press (Inc.) Ltd.

Gray, W. R. \& Hartley, B. S. (1963a). Biochem. J. 89, 379.

Gray, W. R. \& Hartley, B. S. (1963b). Biochem.J.89, 59 P.

Harris, J. I. (1967). In Methods in Enzymology, vol. 11, p. 390. Ed. by Hirs, C. H. W. London: Academic Press (Inc.) Ltd.

Harris, J. I. \& Hindley, J. (1965). J. molec. Biol. 13, 894.

Hirs, C. H. W. (1956). J. biol. Chem. 219, 611.

Ingbar, S. H. (1963). J. clin. Invest. 42, 143.

Kanai, M., Raz, A. \& Goodman, DeW. S. (1968). J. clin. Invest. 47, 2025.
Konisberg, W. (1967). In Methods in Enzymology, vol. 11, p. 461. Ed. by Hirs, C. H. W. London: Academic Press (Inc.) Ltd.

Markert, C. L. (1963). Science, N.Y., 140, 1329.

Michl, H. (1951). Mh. Chem. 82, 429.

Offord, R. E. (1969). In Data for Biochemical Research, p. 526. Ed. by Dawson, R. M. C., Elliot, D. C., Elliott, W. H. \& Jones, K. M. Oxford University Press.

Oppenheimer, J. H. (1968). New Eng. J. Med. 278, 1153. Oppenheimer, J. H., Surks, M. I., Smith, J. C. \& Squef, R. (1965). J. biol. Chem. 240, 173.

Peterson, P. A. (1971a). J. biol. Chem. 246, 34.

Peterson, P. A. (1971b). J. biol. Chem. 246, 44.

Peterson, P. A. \& Beggard, I. (1971). J. biol. Chem. 246, 25.

Purdy, R. H., Woeber, K. A., Holloway, M. T. \& Ingbar, S. H. (1965). Biochemistry, Easton, 4, 1888.

Raz, A. \& Goodman, DeW. S. (1969). J. biol. Chem. 244, 3230.

Raz, A., Shiratori, T. \& Goodman, DeW. S. (1970). J. biol. Chem. 245, 1903.

Robbins, J. \& Rall, J. E. (1960). Physiol. Rev. 40, 415.

Schultze, H. E., Heimburger, H. \& Frank, G. (1962). Biochem. Z. 336, 388.

Waley, S. G. \& Watson, J. (1953). Biochem. J. 55, 328.

Weber, K. \& Osborn, M. J. (1969). J.biol.Chem. 244, 4406. Woods, K. R. \& Wang, K. T. (1969). Biochim. biophys. Acta, 113, 369. 